\title{
International Education beyond State Regulations in Indonesia: Practices from Y Province-Based Public and Private High Schools
}

\author{
Junita Widiati Arfani
}

\begin{abstract}
The objective of this study is to examine implementation of the international education (IE) policy (under the so-called Undang-Undang Sistem Pendidikan Nasional (the Law of National Education System) and its legal derivatives) at high school level in Indonesia by investigating the policy text and its dynamic practices concerning the IE policies at both public and private schools. The study employs qualitative case study methodology combining data collection methods which include individual interviews to key resource persons and documents analysis at national, local and at school levels. Using the Vidovich policy framework, the study explores how national executive, legislative and judicial (states) bodies interact in formulating IE policy and how the policy has impacted at school level. Two schools of public and private that implemented international curriculum were selected as case studies. The study finds that the IE policy that was initially formulated at national level by relevant state authorities/agencies has however resulted in weakening role of the state due in part to its centralized feature (despite its decentralized implementation claim). Consequently, in the stage of its implementation at school level, providers of IE and their champions as non-state actors play significant roles. The study indicates importance and significance of relevant state authorities at local government level in the framework to offer effective supervision on the IE policy implementation.
\end{abstract}

\section{Keywords:}

international education policy; Indonesia; public schools; private schools; state

\section{Introduction}

This article discusses the role of the state in international education (IE) policies at high school level in Indonesia. IE becomes an important issue in the era of globalization as it showed significant growth according to number of schools and countries that are using IE worldwide. For example, the International Baccalaureate Diploma Programme (IBDP), as one of notable IE practices at high school level, has been wide spreading from 7 schools at a time of its first establishment in 1970 to 3,293 schools in 153 countries as of November 2018
(IBO, n.d.). Another prominent IE that qualifies for 5 to 19 years old students, Cambridge Assessment International Education, has been rising to 10.000 schools in 160 countries since the first time of its establishment (Cambridge, n.d.). With those magnificent growth, IE becomes crucial non-state actors in educational sector.

Beginning in 1995, privatization of education become policies in many countries because of the allegiance of negotiations in the World Trade Organization (WTO) General Agreement on Trade in Services (GATS).

-Graduate School for International Development and Cooperation (IDEC), Hiroshima University, Hiroshima, Japan. Email: widiati.arfani@gmail.com 
Robertson (2017) analyzed that the efforts to include education services in the global trade negotiations with its inevitable intervention in the educational regulatory framework have resulted in the growth of the global education market. In turn, it affects the rapid development of IE. In the case of higher education in the developing countries, Enders (2004) has noted that such intervention in the regulatory framework on global education has become a big challenge. While they must adapt with such IE policy, at the same time they must also face the challenges of 'nationalization' of their higher education system and regionalization of the educational system. With the same context, this study tries to contribute to the analysis at the high school level in those three level settings.

At the high school level, the development of IE as a promising trade commodity was marked in the adoption at public school instead of at the private schools. IBO (n.d.a.) reported that in 1970 schools that applied IBDP were only the private schools, but in 2016 among schools that have adopted IBDP, 54\% were public schools and $26 \%$ were private schools. Evidently, IE has been growing up by working with the government (e.g., Ecuador, Japan, and Malaysia). The following questions are therefore raised concerning the issues: what has happened in these countries considering the adoption of IE policies? Does this phenomenon impact to the authority of the nation-state? How does the state perform its authority in the development of IE if it would be against its national interest? To what extent does the role of the state in the development of IE in the country?

In the case of Indonesia, the government released liberalization on education policy that shifts a new direction and practice of internationalization in Indonesian education following the GATS in 1995. According to these regulations, the government reaffirmed that education sector (along with 11 other service sectors) become a commodity and government intervention in these service sectors must be eliminated to increase the export of education services from developed countries to developing countries. Two reasons behind this scheme were: the consideration that the Indonesian government's attention to education is still low and the quality of education in Indonesia is far behind international standards ranging from the level of primary, secondary and higher education (Effendi, 2005). Following this regulation since 1995 private schools using international curricula (mostly western) flourished rapidly. ${ }^{1}$

Under the Law No. 20/2003 on National Education System, the Indonesian government promoted some policies related to international education. the Indonesian government declared its aspiration to having international standardized education in local government area at all levels of education. Two regulations were enacted in accordance to this policy: The Ministerial Regulation No. 78/2009 on the International Standardized School (so called SBI/RSBI policy) and the Ministerial Regulation No. 31/2014 on the Cooperation in the Implementation and Management of Education by Foreign Education Institutions with Educational Institutions in Indonesia (so called SPK policy). The previous policy seems to be directed to public schools and for even distribution in quality of education and later appears to control private schools using an international curriculum. With such background, this article tries to examine the

\footnotetext{
${ }^{1}$ Before the 1990s the number of international schools were few and were established only for expatriates and applied home country curricula such as Jakarta International School (1950, American Curriculum), Gandhi Memorial School (1951, British Curriculum), Deutsche Schule Jakarta (1957, Germany curriculum) and Jakarta Japanese School (1978, Japanese curriculum). After the liberalization of education policy was launched, more than 30 private international schools were founded between the 1990s to early 2002, accepting expatriate and Indonesian citizen student. Recently, there are more than 500 international schools all over the country.
} 
role of the state of Indonesia in international education by looking closer to the policy practices at school level, both in public and private school. It is guided by three research questions: what were the key influences that impacted on the initiation and on the development of IE policies in Indonesia? What policy implementation practices were evident in the two case study schools? While the first was considered to understand IE policies at national level, the second research question is intended for elaborating IE policies at the local and school level.

\section{Conceptual Framework \\ Policy as a cycle process}

The study adopted the Vidovich (2001) framework that developed from Ball conceptualization of policy analysis which includes three principle contexts: the context of influence, the context of policy text production and the context of practices/effects (see figure 2). The context of influence means all the factors that nourished the policy text production at each level; macro, intermediate and micro level. In this study the analysis of micro level influences derives from the two different types of institutions (schools) with "specific localized context" (Vidovich, 2001, p. 13) based on organizational background (public and private), historical background (old and new), population (big and small scale) in the same level (high school level). The context of policy text production is "constituting a textual 'policy document' or an official spoken requirement (verbal text) on expected behaviors" (Jones, 2013). In figure 1 , the arrows between each level refer to the interconnection between them. Context of practices/effects is seeing how the policy is being interpreted and executed. The Vidovich framework is a synthesis of a modernist approach that emphasizes the important role of the state in policy processes and a postmodernist approach that, on the contrary, is more consider other actors such as civil society or NGOs in public policymaking. It emphasizes the processes and consequences of policy-making process. Vidovich framework also gives greater recognition to the influence of global forces. Figure 2 shows the Vidovich policy analysis model that is relevant for this study.

\section{Figure 1.}

\section{A Modified Policy Cycle: Incorporating Macro Constraint and Micro Agency}

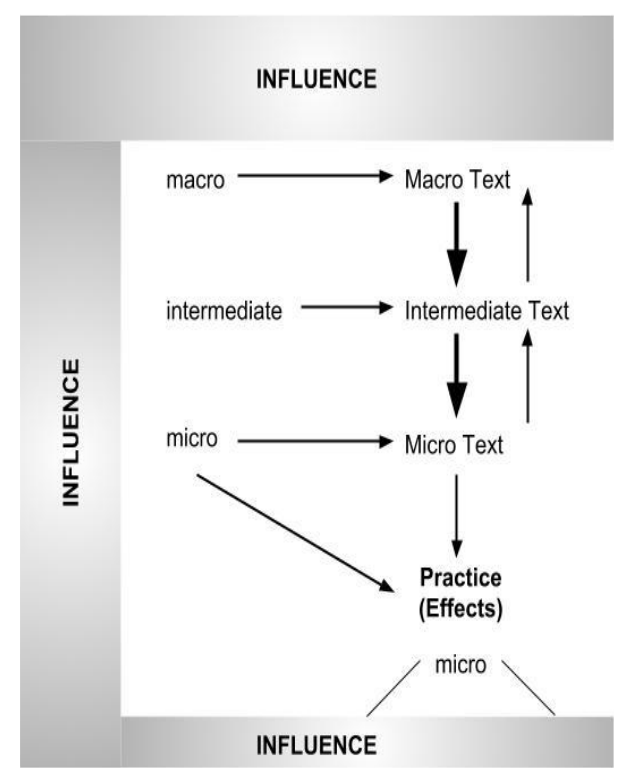

Source: Vidovich, L. (2001).

\section{Literature Review}

The term of IE is often interchangeably with the term international school (Hayden \& Thompson, 1995), international mindedness (Hill, 2012; Haywood, 2015), education for international understanding (UNESCO, 2018) or international school system (Lauder, 2015). It has also been defined with many conception such as 'foreign society and cultures formal schooling' (Matthews, 1971 as cited in Sylvester, 2005); 'education for responsible citizen involvement and effective participation in global society' (Anderson \& Becker, 1976, p. 8 as cited in Sylvester, 2005); 'an international force in the modernization process, direct preparation and specialized training for active participation in the international processes' 
(Butts, 1971 as cited in Sylvester, 2005) and 'an association with the crossing of frontiers, be they physical or intellectual' (Hayden \& Thompson, 1995, p. 51). By synthesizing the thoughts, this study considers IE as the dimension of education concerning with the certain foreign curricula and an international school system which can be applied to a local school aiming for cultivating the international mindedness or international understanding.

Sylvester (2005, p. 313) proposed a mapping of the various definitions of IE in a modeling matrix (see Figure 2). He divided into four areas consider with four elements. The two elements represented pragmatic values (education for international understanding) and idealistic values (education for world citizenship) and the other two elements reflected political sensitiveness. On the center of those area referred to the position defined by Kandel (1957 as cited in Sylvester, 2005, p. 313) which 'IE must grow out of national system of education and cannot be transplanted from above or beyond the nation-state'. This study agreed with this position.

\section{Methods}

To answer the research questions, this study applied a qualitative case study approach presenting in-depth description and analysis of enclosed system (Merriam \&Tisdell, 2016). A combination of data collection for triangulation were set. First, from the analysis of government policy documents at a national and local level, and curriculum documents at a school level. The data was also collected from the news to capture the discourses surrounding the enactment of the policy. Second, from semistructured interviews that were conducted with program coordinators who are also a teacher, and with the administrator. Two case schools using IE program in city $\mathrm{Y}$ of Indonesia were chosen. The two case schools have a different type that is a public (school A) and a private school (school B). This is unique because even though the SBI/RSBI policy had been annulled, the case school $\mathrm{A}$ is one of public schools that still maintains IE. While the case school B represented private schools that affected by the recent SPK policy. From picking up the two types of school, we could find the evident of policy implement practices representatively.

The main purpose of interviews is to obtain a special kind of information (Merriam \& Tisdell, 2016) or "conversation with purpose" (Dexter as cited in Merriam \& Tisdell, 2016). In the case schools, some questions were asked to the key persons. All the participants use pseudonym, assigned by the author with initial alphabetical order for ethical reason. At the school A, one ex-program coordinator who retired the previous year (Mrs. Ani) and recent program coordinator (Mrs. Berti) were interviewed. Mrs. Ani found as key person as she had been involved since the program was initiated: e.g. initial correspondence with international education institution, delivering the curriculum, designing the student report, homeroom teacher until evaluating the first class. At the school B one program coordinator (Mr. Chandra) and one administrator (Mr. Danu) were interviewed. The Interviews do provide a clear picture of what is happening at the school level as a result of government policies on the international education and thus it gives the basis for an analysis of the position of the state.

\section{Results and Discussion \\ Indonesian education system and the international education policy}

After its independence in 1945, Indonesia as a new big country (an archipelago state with more than 13.000 islands and 300 tribes) decided an education system as a basic tool to achieve the national goal as stated in the Constitution of the Republic of Indonesia 1945 Chapter 31 article 2:

“The government organizes and implements a national education 
Figure 2.

IE Definitions in Matrix Modeling

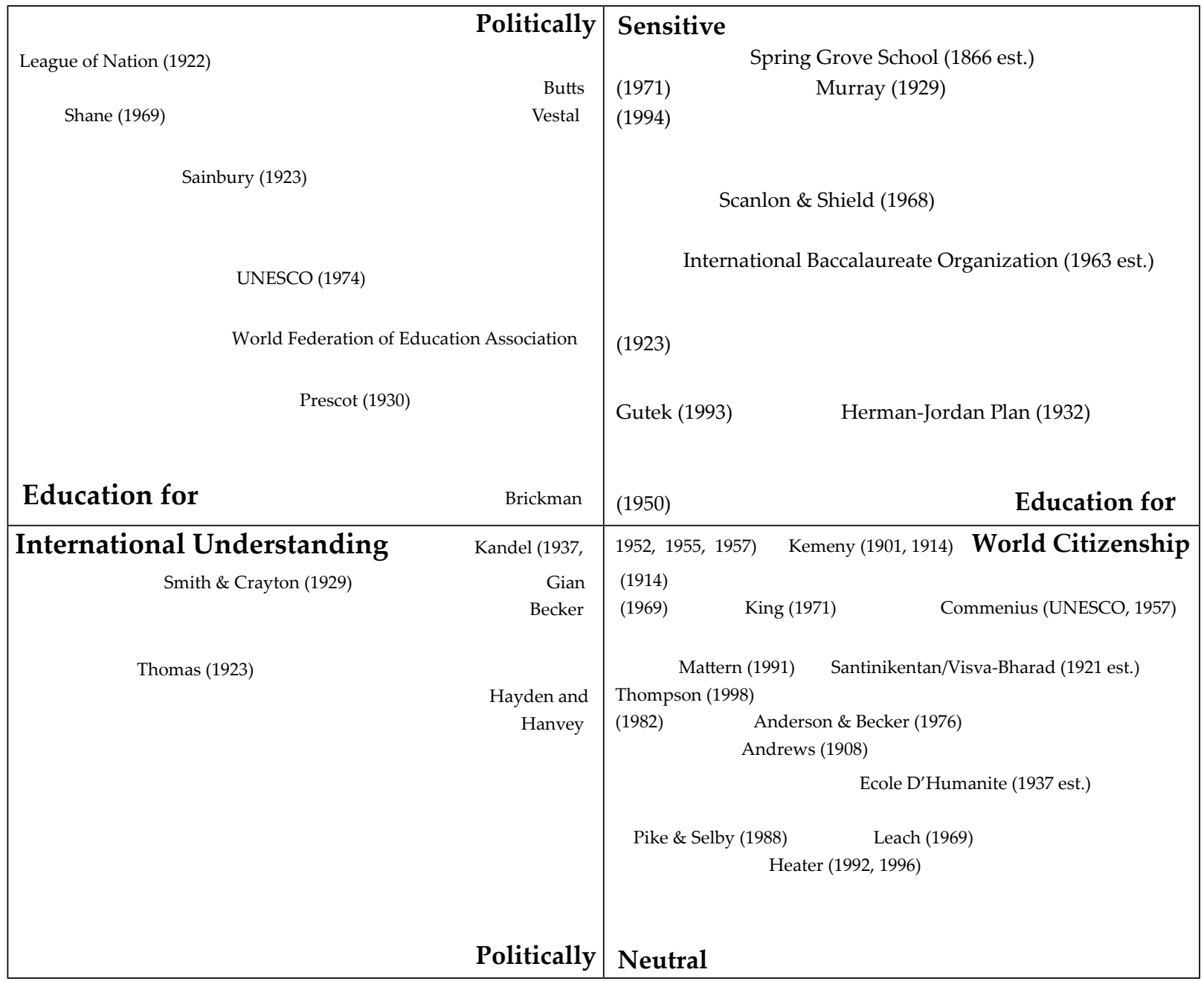

Source: Sylvester (2005)

system, to be regulated by law, that aims at enhancing religious and pious feelings as well as moral excellence with a view to upgrading national life."

The education system was promulgated on the Law No. 4/1950 juncto Law No. 12/1954 concerning the basic foundation of education and teaching in schools for all over Indonesia. There were two basic principles that encouraged this policy: First, based on the national interest and anti-colonialism, the education system must be rooted from the Indonesian values and culture. Second, based on the democratic value, the education must be delivered to all Indonesian people without exception. This policy was the response upon the situation in the colonialism era in which it was dominated by the Dutch school curriculum and only elite Javanese groups has the privilege to go to school (Ledger, 2013).

The obvious strategies for this policy was to promote Indonesian language as the only language of instruction in schools. As the study of Leigh (1999) revealed, until the 1960s, the primary task of teachers was to instill the 'Indonesianness' by using Indonesian language in classes (p. 47). In such conditions, schools that offered foreign curriculum with 
foreign language were only permitted to serve for children from embassy and expatriate family (e.g. Jakarta International School 1951, Deutsche Schule 1957). Hence, the international education was considered as a threat to the development of strong national or cultural identity (Hayden, Levy, Thompson, 2015).

These conditions found its shifts along with the wave of globalization that emerged in the late 1980s. Based on the Law No. 02/1989 concerning the National Education System and Government Regulations No. 29/1990 concerning the Secondary Education, the government permitted the foreign expertise to be engaged in a national education institution and allowed foreign parties to establish the secondary education level only for the foreign student (Article 34). Even though the policy was prohibited for Indonesian citizen, it signaled the opportunity for the development of IE.

The openness to the IE was more tangible under the new Law No. 20/2003 concerning the national education system. The Indonesian government has declared its aspiration to having international standardized of education in local government area at all level of education (article 50). The government also allows foreign entities to organize education activities at the basic and secondary level of education in conjunction with local institutions (Article 65). Two regulations were promulgated in accordance to this policy: The Ministerial Regulation No. 78/2009 on the International Standardized School and the Ministerial Regulation No. 31/2014 on the Cooperation Education Unit (Satuan Pendidikan Kerjasama/ SPK).

\section{Internationalization at public schools}

The Ministerial Regulation No. 78/2009 was directed to public schools and private schools using national curriculum aiming the improvement and even distribution in quality of education. In 2013, preceded by a series of protests by the education activist and a teachers union, the Indonesian Constitutional Court accepted the judicial review over the Act No. 20/2003 article 50 and agreed that the implementation of international standard school has violated the principle of 'education for all', encouraged elitism, and worked against the position of Indonesian as a unifying language by using English as the language of instruction (Constitutional Court Decision No. 5/ PUU-X/2012). Based on this decision, the Act No 20/2003 article 50 and all the derivative regulations were annulled. It means that this international education policy was cancelled before achieving the targets (Arfani \& Nakaya, 2018).

Even though, one of the members of the Constitutional Court stated his opinion to the Jakarta Post that "the scrapping of RSBI and SBI would be a major blow to efforts to provide better education for the country's citizens. RSBI and SBI are still concept schools, their dissolution will mean a waste of funds, which have already been used in the pilot project. It will also thwart government efforts to improve the quality of education" (Parlina \& Aritonang, 2013). In addition, The Minister of Culture and Education stated right after the Constitutional Court decision that "one thing is certain. The schools will not be shut down" (Parlina \& Aritonang, 2013). This situation leads to the vagueness of the implementation of Constitutional Court Decision No. 5/PUU-X/2012. The study of Laksono et al.(2013) has revealed that there was a confusion over the Constitutional Court decision which resulted the difference reaction from the school. Some RSBI schools responded spontaneously to stop the program and removed all the attributes concerning the RSBI program but the other responded formally and waited for the instruction from the ministry of education and culture. Amid the turmoil, the Ministry of Education and Culture issued a Circular Letter No. 017/MPK/SE/2013 on the agreement between the Ministry of Cultural 
and Education and Constitutional Court which permitted a transition period in the cancellation of international programs in RSBI schools to return to regular schools with the national curriculum. The case school A has been one of the public schools which still implements the IE program until the study was conducted so far.

\section{Internationalization at private schools}

The Ministerial Regulation No. 31/2014 govern the cooperation between foreign and Indonesian education institution, designated as SPK/Satuan Pendidikan Kerjasama (a joint-cooperation on education) school, with centralized mechanism. It requires a mandatory permission as well as supervises from the Ministry of Education and Culture. A recommendation from the local government is needed only at the establishment stage.

The regulation also stated that SPK consist of Indonesian citizens and is forbidden from refusing Indonesian citizen student (Article 8). In terms of the curriculum, SPK are obliged to provide religious education, Pancasila and Civic studies, and Indonesian language to the Indonesian citizen student (Article 11). Those subjects must be conducted with Indonesian language as medium of instruction in which a foreign language is allowed for the explanation (Article 12). This policy does not modulate

Table 1.

Summary on international education policy in Indonesia

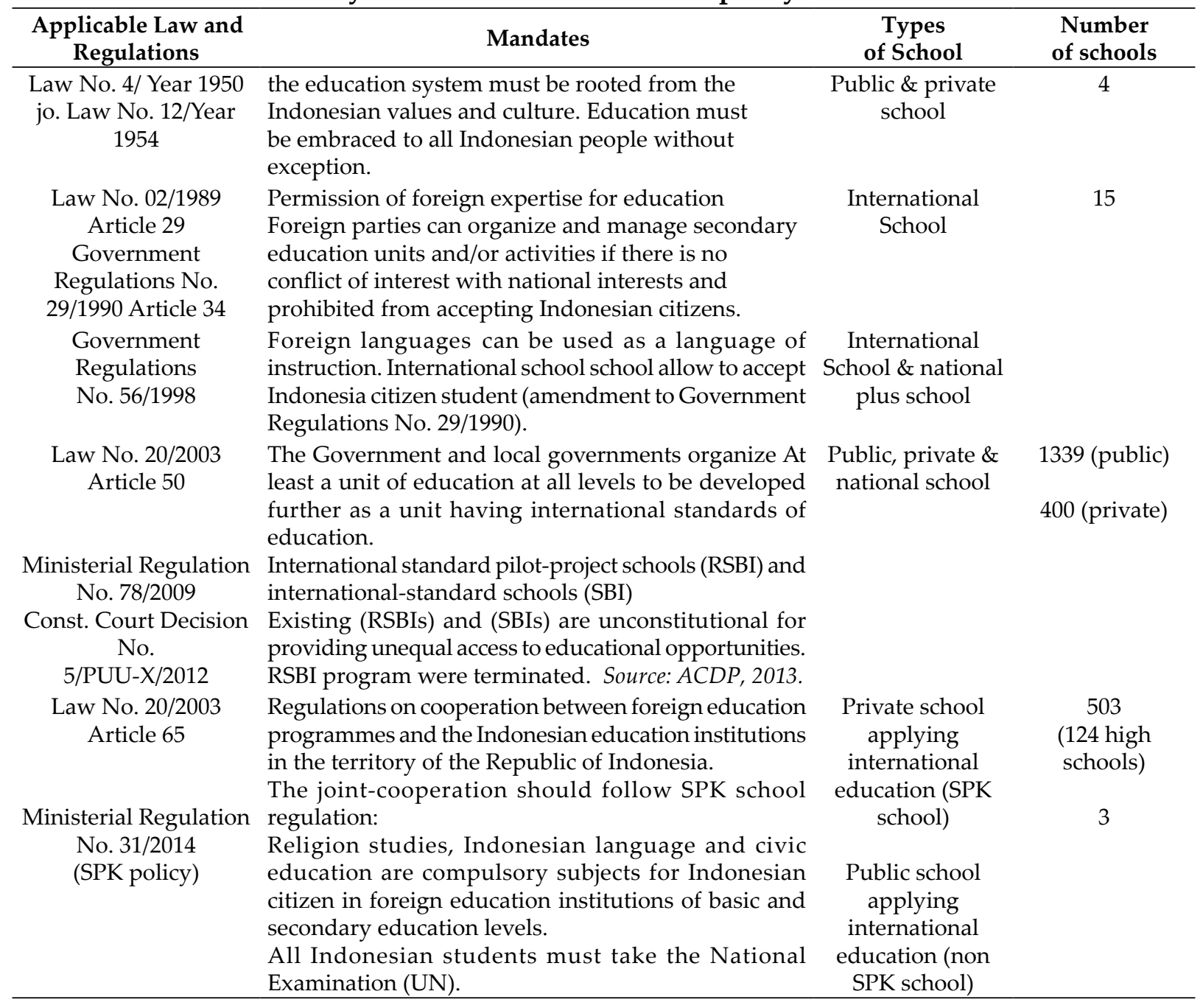

Source: obtained from secondary data 
how the two curriculums were combined and therefore, it seems that the government give room for the IE schools (SPK) to deal with it.

\section{Two case study schools}

The two case study schools were different types of institutions with different histories, as described on their web pages, school document and other resources. The High School A is a public school with long history back to the colonial era in 1919 called Algemeene Middelbare School afdeeling $A$. It was established by the Dutch as a part of the Dutch ethics politics of a middle level school combining east and west education and was served for indigenous people (Dhakidae, 2003). In 1957, the school was ordered to implement the new curriculum based on the Law 1954. After that the school underwent a series of curriculum change and it always becomes a pilot school of every program/ new curriculum policy prior to national roll-out: applied program school counseling program in 1961, Excellent School policy in 1998, first school that applied acceleration program 2002, first opened international class program using Cambridge curriculum in 2004, predicated as Sekolah Nasional Berstandar Internasional/SNBI (International Standard Based School) in 2005, and under the enactment of the Minister Regulations of RSBI policy the predicate of SNBI was changed into RSBI school in 2006. It was the first RSBI school in Indonesia and become a pilot school of this policy. As of January 2019, this school has 29 classes with 67 teachers and 686 students. One class of 28-29 students per grade is international class Cambridge Curriculum. Despite the fact that SNBI/RSBI was terminated and replaced by SPK regulation, this school that previously implemented RSBI has not been officially implemented SPK since then.

The High School B was a small-scale international school founded in 1989 by a private foundation consist of 5 board members of 3 Indonesia citizens and 2 foreigners.
Under one foundation, the school was operated from primary to secondary level based on Cambridge international (IGCSE) curriculum. In 2014, following Ministerial Decree No. 31/2014 on the cooperation and management of foreign education institutions with Indonesian education institutions, the Ministry of Education and Culture issued four separate licenses of SPK to this school for its early years' education, primary school, Junior high school and senior high school. In 2015 the IGCSE curriculum was changed and it was authorized as International Baccalaureate (IB) School, applied from elementary called Primary Years Programme (PYP) to secondary level namely Middle Years Programme (MYP) and the Diploma Programme (DP) (IBO, 2019). Based on the Ministerial Instruction that 'SPK schools are prohibited from using the word 'International' to name educational units, programs, classes, and/or subjects' (chapter VII, article 5), the school was renamed with a new name without "international". As of January 2019, the Diploma Programme (high school level) has 4 teachers and 19 students (Indonesia citizens and foreign students) that shared in three grades.

The section below sought to answer the research question two: What policy implementation practices were evident in the two case study schools? The interviews to the program coordinator and the administrator was unraveled under the sub topic as follows: the initiation process of adopting IE, the implementation strategies toward the IE policies, degree of success, obstacles and effort to overcome.

\section{Initiation process of adopting IE}

There were two issues emerged in the initiation process of adopting IE: reason for applying IE and the actor or key person behind the adoption of IE. For the reason of applying IE, one school admitted the urge of being a pioneer among the public schools and the other school 
admitted for its high quality of IE. The second reason was adopted by a school in which they change from one IE into another for higher quality. Even though the two reasons were taken in different conditions, both has clarified Visser's (2010) study, whereas schools utilize the IB to gain 'competitive advantage' (Porter, 1985, p.3) among other similar IE schools and to 'reinvigorate their organizational survival' (Kazuhisa, 2018) in order to survive in the education market. Evidently, it realized that there is also a competition in the IE intensemarket.

Related to the actor, it revealed that the principal plays an important role in public school and the founder or board member is the parties who have significant part in the at the private school. There was no statement that other parties such as government took part in the initiation.

\section{Case school A:}

“...It began from principal's idea and that was before the government enacted the RSBI policy. At that time, the Principal was thinking of what other flagship programs we could apply next. The school has been predicated as an "excellent school" and a "school of character education". So, he thought, "How about we try to extend the school to an international level? We can be the pioneer.... to open up the IE program is not that easy...it took a long time. We discussed it everywhere and until night...It was before 2004, the principal asked 6 senior teachers (including the participant) to be the core team and we had a discussion with the alumni, who were at that time a high-rank university lecturer, about how to be an IE school. But discussing it with smart people didn't take us anywhere, they just full of arguments with so many considerations, we didn't have any conclusion... But the principal insisted to be an international school one. So, we (the core team) agreed to open an international program in our school. However, we still had no idea what kind of IE and what should we do? Then the principal sent us to the private international school in Jakarta and Bali to have a comparative study. After comparative studies, I said to the principal how if we apply Cambridge, and directly (contact) to Cambridge. The principal agreed. I myself made an initial contact with the Cambridge Center, correspondence with them to learn how it (the system) works. Since we did not have any internet access at school, I did it in a rental internet near my house. I did also at school holidays. They (the Cambridge Center) was very responsive...." (Mrs. Ani, personal communication, January 15, 2019)

Case school B:

"...There was a deep discussion of choosing the IE program among the founders of the school. What IE program should be adopted. There were two opinions which are Cambridge or IB. It decided to use Cambridge because the IB requirement is so high, at that time we cannot fulfilled the IB requirement yet because of our limitation in infrastructures. So, the school adopted Cambridge. But the board member keeps the desire. In 2013 we apply for IB school. We got authorization as IB school in 2015. It's a matter of quality...." (Mr. Chandra, personal communication, February 14, 2019)

"About the same time the government enforced the new policy for the international school. We were asked to decide the type of school. And the board member decides to be 
an SPK school because we adopt the IE curriculum and we already have mixed student of Indonesian and foreign student." (Mr. Danu, personal communication, February $14,2019)$

The study of Kazuhisa (2018), compiling the experiences of the IE schools in many countries, revealed that the 'practical needs and desire' to give the impression to the school stakeholders and 'to gain a better position in an education (or a quasi-education) market' become the factors enforcing the initiator of IE schools (Kazuhisa, 2018). To some degree, Kazuhisa's analysis in line with the findings of this study.

\section{Implementation strategies under the IE policies}

This study revealed that schools has created its own policy in accordance to the allegiance to the government policy and to accommodate with the needs of the school.

The case school A:

"Since the RSBI policy was terminated, and the 'RSBI' nameplate was revoked, the principal brought the IE program into the Special Service Program (Program LayananKhusus/PLK) along with Research Program and Accelerated Program. Students are offered to join the program at the time of the selection of new students. We explain this SSP in parents gathering and they must sign a contract at the beginning of the program. The hours of the Cambridge program learning are inserted after the National curriculum lesson hours." (Mrs. Berti, personal communication, January 14, 2019)

The case school B:

"We delivered the 'compulsory subject' of SPK (Religion, Pancasila and Civic, Indonesian Language) along with IBDP curriculum.
It means that no school hour added. As religion, Pancasila and civic delivered in TOK (Theory of Knowledge) ...Following the regulations, Indonesian student take the National examination. Even though, we had experienced that one of our students has accepted in foreign university before he took National Examination. The university he applies for recognized his IBDP certificate. Anyway, we did not announce this to student as a possibility, 'there is a door, but we do not open it'." (Mr. Chandra, personal communication, February 14, 2019)

“... it has been continuously checked, routinely by the ministry (of education and culture). On behalf of the school, I was also called to Jakarta for socialization. There is no supervision from the local government." (Mr. Danu, personal communication, February 14, 2019)

This is in line with the statement of the chief of the Local Board of Education which indicate that local level authorities were not empowered by the policy as it conducted and controlled by the Ministry of Education and Cultural (Hafil, 2014).

\section{Degree of success}

The success for IE case study schools is interpreted as they boast their students graduate completely with two curriculums and continue their study to the high rank university both in the country and abroad.

\section{Case school A:}

"When we tried a blended curriculum to overcome the difficulties in managing two curriculums, we do collaborative work. It was hard work, but it runs well. That's why we become a pilot school. we tried a blended curriculum. And it was 
followed by public school all over the country ...The 25 students were very smart student. That was the reason why this program succeeds. Moreover, the teachers. It was not just the senior teacher at the school who was assigned to teach in this international program but also from the alumni who are lecturer in the (first rank in the country) university." (Mrs. Ani, personal communication, January 15, 2019)

\section{Case school B:}

“...Our students have been spread out in many universities. In addition, there is one of our students that had already accepted at the university without submitting the National Examination results. This means that the university recognizes the IBDP certificate." (Mr. Danu, personal communication, February 14, 2019)

This underlined how they expressed themselves as success school as stated in the school website:

"Over the past 30 years students from YIS have gone on to be accepted into some of the world's leading universities; they have become doctors and lawyers, designers, business owners, artists, leaders and critical thinkers. While YIS is proud of their achievements, we are equally proud of the curious, empathetic and confident young adults they become; individuals who are inspired to navigate their own independent journey through life."

\section{Obstacles and the effort to overcome}

In the implementation of IE, the two case schools had to find themselves struggling with some difficulties. In public school, teachers' confidence and different vision from the changing principals were mentioned as problem. Another problem mentioned is the ambiguity of the local government in positioning the adoption of IE in public school. This ambivalence of local government and the confusion of the school could be understood in accordance to SPK regulations, particularly in the article 25 of establishing IE school (SPK) that request and granting for recommendation to the regional government (regency/city and/or province). Even though, this confusion does not make the school cancelled the program since it is a flagship program of the school.

In this sense, we can understand this school choice by utterance of 'market driven' (Matthews, 1988 as cited in Hayden \& Thompson, 1995; Hill, 2000) in which the school try to extend more educational services than other public school 'in response to the needs of a group of students who are not catered for by the education provided in local, nationally based, school' (Hayden \& Thompson, 1995).

\section{Case school A:}

"Major difficulties have been on the teacher's confidence and effort. We must train our teachers especially in using English as a medium of instruction. Some of them even felt under pressure. But I said this is not merely an English program, we are International standardized. It is ok using Indonesian language especially when we must explain the basic concept. They felt relieved. There was a misunderstanding, they thought teaching with English as medium of instruction was the only way. That's wrong. Other difficulty we faced is the changing of principal who has different vision. Doing IE with national curriculum need a good teamwork. It would be difficult if the principal does not support it. ...It is hard to adopt it separately, so we blend the material that overlap. It is a problem to us. It is not easy to blend the two curriculums... We 
need good teachers in this matter. We keep going on the program because we have been applying this program before the government enacted the RSBI policy. This is the flagship program of the school. I think as long as the principal support this program, it will go through." (Mrs. Ani, personal communication, January 15, 2019)

"I heard that we (the public school, red) cannot apply such IE anymore (since the termination of RSBI policy). We have already proposed a recommendation to the board of education (district government) as one of the requirements to be an SPK, but they did not give it. On the other hand, they ask us to keep running this program. That confused us." (Mrs. Berti, personal communication, January 14, 2019)

The study finds that schools also face up the difficulty in the implementation of dual curriculum: IE and National Curriculum as it stated by the two case schools above and below. In response to this, IBDP coordinators who routinely held meetings have submitted proposals to the central government to consider the recognition of IB examinations to be equivalent to UN and so students do not need to take both as stated below:

\section{Case School B:}

"I think it is difficult for the student to be successful in both. At the meeting of Indonesia IB School Coordinator at Jakarta we propose to the Ministry of Education and Culture to consider IB Examination as equivalent with National Examination, so we can focus on the quality of the examination result." (Mr. Chandra, personal communication, February $14,2019)$

\section{Conclusion}

The dynamics of the state in IE Policies have been played in Indonesia since three decades. In the context of global influence, attachment to world-level WTO organizations within the framework of the GATS agreement had initiated the education liberalization policy including in the level of secondary education. Under the enactment of the 1989 Education Law, the "nationalistic" policy in which it avoids the western influences as a reflection of the colonialism has shifted into "internationalistic" policy. The enactment of the 2003 Education Law revised the previous by trying back to instill nationalism while further strengthened the policy of IE growth and even ensured the rights of Indonesian citizens to get the IE.

In such circumstances, IE policy that was initially formulated at national level by relevant state authorities/agencies has however resulted in weakening role of the state due in part to its centralized feature (despite its decentralized implementation claim). As this study revealed, it resulted a consequence that in the stage of its implementation at school level, providers of IE and their champions as non-state actors play significant roles.

The study was constructed by the assumption of the exigency of the state to achieve its goal through education in which the IE becomes a tool of acceleration. Therefore, the most important part is how the state carried out its role in managing IE as a strategy to achieve that national education goal. More concrete, the government must have an ideal vision of balancing between 'nationalistic' and 'internationalistic' policy and diligently formulate concrete measures by which to achieve it. The study indicates the importance and the significance of relevant state authorities at local government level in the framework to offer effective supervision on the IE policy implementation. Thus, it 
suggests that empowered local government educational authorities is a prerequisite for successful implementation of IE policy as they are devised with better comprehension of local needs and situation.

\section{References}

ACDP.(2013). Evaluation of international standard schools in Indonesia. Retrieved from https://www.adb.org/sites/default/ files/publication/176607/ino-evaluationinternational-standard-schools.pdf.

Arfani, J. W. \& Nakaya, A. (2018). Unpublished article. Japan: Hiroshima University.

Cambridge. (n.d). Our history. Retrieved from https://www.cambridgeinternational.org/ about-us/our-history/

Dhakidae, D. (2003). Cendekiawan dan kekuasaan dalam negara Orde Baru. Jakarta: Gramedia Pustaka Utama.

Effendi, S. (2005, September 22). GATS dan liberalisasi pendidikan tinggi. Speech presented at GATS: Neo-Imperialisme modern dalam pendidikan in Indonesia, Yogyakarta. Retrieved from http:// sofian.staff.ugm.ac.id/artikel/GATS-danLiberalisasi-Pendidikan.pdf

Enders, J. (2004). Higher education, internationalisation, and the nation-state: Recent developments and challenges to governance theory. Higher Education, 47(3), 361-382.

Hayden, M., \& Thompson, J. (1995). International schools and international education: A relationship reviewed. Oxford Review of Education, 21(3), 327-345. doi: 10.1080/0305498950210306

Hayden, M., Levy, J., \& Thompson, J. (2015). Introduction to the second edition. In M. Hayden, J. Levy, \& J. Thompson (Eds.), The Sage Handbook of Research in International Education (pp. 1-27). London: Sage Publications.

Haywood, T. (2015). International mindedness and its enemies. In M. Hayden, J. Levy,
\& J. Thompson (Eds.), The Sage Handbook of Research in International Education (pp. 45-58). London: Sage Publications. Hafil, M. (2014). Sekolah Internasional harusnya tidak menerima siswa WNI. Republika.co.id. Retrieved from https:// www.republika.co.id/berita/pendidikan/ education/14/04/29/n4s6w6-sekolahinternasional-harusnya-tidak-menerimasiswa-wni

Hill, I. (2000). Internationally minded school. International Schools Journal, XX(1), 24-37.

Hill, I. (2012). Evolution of education for international mindedness. In T. Bunnell, M. Hayden, \& J. Thompson (Eds.), International Education (pp. 177-196). London: Sage Publications.

IBO (n.d.). Find an IB world school. Retrieved from https://www.ibo.org/programmes/ find-an-ib-school/ .

IBO. (n.d.a). The history of the IB. Retrieved from https://www.ibo.org/globalassets/digitaltookit/presentations/1711-presentationhistory-of-the-ib-en.pdf.

Jones, T. (2013). Understanding education policy: The four education orientations. New York: Springer.

Kazuhisa, H. (2018). The reason why schools adopt the International Baccalaureate Programmes: A review of the literature. The Tsuru University Review, 87, 223-239.

Leigh, B. (1999). Learning and knowing boundaries: Schooling in new order Indonesia. Sojourn: Journal of Social Issues in Southeast Asia, 4(1), 34-56.

Ledger, S. (2013). The International Baccalaureate in remote Indonesian contexts: A global to local curriculum policy trajectory (Doctoral dissertation, The University of Western Australia, 2013). Perth, Australia: The University of Western Australia.

Laksono, F., Wijayanti, W.,Triningsih, A., Mardiya, N. Q. (2013). Implikasi dan implementasi putusan Mahkamah Konstitusi No. 5/PUU-X/2012 tentang 
RSBI dan SBI. Jurnal Konstitusi, 10(4), 731-760.

Lauder, H. (2015). International school, education and globalisation: Towards a research agenda. In M. Hayden, J. Levy, \& J. Thompson (Eds.), The Sage Handbook of Research in International Education (pp.172181). London: Sage Publications.

Merriam, S. B. \& Tisdell, E. J. (2016). Qualitative research:A guide to design and implementation. San Francisco: Jossey-Bass.

Porter, M. E. (1985). Competitive advantage: Creating and sustaining superior performance. New York, NY: The Free Press.

Republic of Indonesia. (1945). Constitution of the Republic of Indonesia 1945.

Republic of Indonesia. (1950). The Education System (Law No 4/1950). Jakarta: Secretary of State of the Republic of Indonesia.

Republic of Indonesia. (1989). National Education System (Law No. 02/1989). Jakarta: Ministry of National Education.

Republic of Indonesia. (1990). The Secondary Education (Government Regulations No. 29/1990). Jakarta: Ministry of State Secretariat.

Republic of Indonesia. (1998). Amendment on Government Regulation No. 29/1990 on the Secondary Education (Government Regulations No. 56/1998). Jakarta: Ministry of State Secretariat.

Republic of Indonesia. (2009). International Standardized School (Ministerial Regulation No. 78/2009). Jakarta: Ministry of Education and Culture.

Republic of Indonesia. (2013). Transition of RSBI Policy (Circular Letter No. 017/MPK/ SE/2013). Jakarta: Ministry of Education and Culture.

Republic of Indonesia. (2003). National Education System (Law No. 20/2003). Jakarta: Ministry of National Education.

Republic of Indonesia. (2014). Cooperation in educational management and provision between foreign education agencies and education agencies in Indonesia (Ministerial Decree No. 31/2014). Jakarta: Ministry of Education and Culture.

Republic of Indonesia. (2012). Constitutional Court Decision Number 5/PUU-X on the status of the law supporting International Standard Schools in Indonesia. Jakarta: Constitutional Court.

Robertson, L.S. (2017). Making education markets through global trade agreements. Globalisation, Societies and Education, 15(3), 296-308. doi: 10.1080/14767724.2017.1345408

Parlina, I., Aritonang, M. S. (2013, January 9). Court rules international-standard schools illegal for unequal access. The Jakarta Post. Retrieved from https://www. thejakartapost.com/news/2013/01/09/ court-rules-international-standardschools-illegal-unequal-access.html

Sylvester, R. (2005). Framing the map of international education (1969-1998). In T. Bunnell, M. Hayden, \& J. Thompson (Eds.), International Education (pp. 293317). London: Sage Publications.

United Nations Educational, Scientific and Cultural Organization (UNESCO). (2018). Education for international understanding: Examples and suggestion for classroom use. Retrieved from https://unesdoc.unesco.org/ark:/48223/ pf0000000011

Visser, A. (2010). International education in a national context: Introducing the International Baccalaureate Middle Years Programmein Dutch publicschools. Journal of Research in International Education, 9(2), 141-152. doi: 10.1177/1475240910370816

Vidovich, L. (2001). A conceptual framework for analysis of education policy and practices. Paper presented at The Australian Association for Research in Education in The University of Western Australia, Perth. 